\title{
Tectonic Background of Four Hydrothermal Fields Along the Central Indian Ridge
}

\author{
Kyoko Okino, Kentaro Nakamura, and Hiroshi Sato
}

\begin{abstract}
Since the discovery of the Kairei hydrothermal field at the southernmost end of the Central Indian Ridge (CIR) in 2000, only four active hydrothermal vent fields have subsequently been discovered. These four hydrothermal fields show remarkable diversity in the chemical compositions of fluids and associated ecosystems. Focused geophysical mapping and rock sampling indicate that different tectonic setting constrains the different hydrothermal activity for each field. Two hydrothermal fields in the southern CIR are located on the axial rift-valley wall. The hydrogen-rich Kairei hydrothermal field at $25^{\circ} 19^{\prime} \mathrm{S}$ is constrained by both basaltic magmatism and detachment faulting that exhume ultramafic rocks on a shallow subsurface, whereas no evidence of ultramafic exposure is recognized in the typical mid-ocean ridge type Edmond hydrothermal field at $23^{\circ} 52^{\prime} \mathrm{S}$. Two other hydrothermal fields have been newly discovered in the central CIR. The Solitaire field at $19^{\circ} 33^{\prime} \mathrm{S}$ is located about $2.6 \mathrm{~km}$ away from the neo-volcanic zone and is likely influenced by intra-plate volcanism. The Dodo field at $18^{\circ} 20^{\prime} \mathrm{S}$ is located at the center of the axial valley floor, where a basaltic sheet-lava flow buries the seafloor. The lava morphology and the existence of an adjacent large off-axis seamount support the idea that excess melt is supplied in this segment. The anomalous magmatism is likely influenced by mantle plume components or by a large-offset transform fault just north of the segment. The large diversity found in the four hydrothermal fields along the CIR provides important insights on the tectonic control of global hydrothermal systems.
\end{abstract}

\section{Keywords}

Geological background • Gravity • Hydrothermal system • Indian Ocean • Magnetics

- Morphology $\bullet$ Rock geochemistry

K. Okino $(\bowtie)$

Atmosphere and Ocean Research Institute (AORI), The University of

Tokyo, 5-1-5 Kashiwanoha, Kashiwa, Chiba 277-8564, Japan

e-mail: okino@aori.u-tokyo.ac.jp

\section{K. Nakamura}

Department of Systems Innovation, School of Engineering, The University of Tokyo, 7-3-1 Hongo, Bunkyo-ku, Tokyo 113-8656, Japan

Precambrian Ecosystem Laboratory (PEL), Japan Agency for MarineEarth Science and Technology (JAMSTEC), 2-15 Natsushima, Yokosuka, Kanagawa 237-0061, Japan
Submarine Hydrothermal System Research Group, Japan Agency for Marine-Earth Science and Technology (JAMSTEC), 2-15 Natsushima, Yokosuka, Kanagawa 237-0061, Japan

H. Sato

School of Business Administration, Senshu University, 2-1-1 Higashimita, Tama, Kawasaki, Kanagawa 214-8580, Japan 


\subsection{Introduction}

The diversity found in global hydrothermal systems in relation to their size, evolution, fluid geochemistry, and associated ecosystems, is largely constrained by the chemical and physical conditions of the sub-seafloor; in particular, the geological and tectonic settings surrounding the system. The TAIGA project team hypothesize that there are four types of sub-seafloor aquifers (TAIGAs: great rivers in Japanese), which are divided based on their representative chemical energy: compounds of sulfur, carbon (methane), iron, and hydrogen (Urabe et al. 2009; Chap. 1). During the TAIGA project, we study each type of sub-seafloor aquifer, in an attempt to reveal how the geological and tectonic setting controls the hydrothermal activity.

The Central Indian Ridge (CIR) is one of the most intensively-studied fields where unique hydrogen-rich hydrothermal vent is known to exist. At present, only four hydrothermal vent fields have been visually confirmed along the CIR; two of which were newly discovered during the TAIGA project. Other plume anomalies have been reported in the water column along the CIR (e.g., Park 2010) and previous German expeditions reported the fossil hydrothermal sites (e.g., Herzig and Pluger 1988; Halbach et al. 1995) The active hydrothermal vent fields are described as follows.

The Kairei hydrothermal field (KHF), located at the southernmost CIR near the Rodriguez Triple Junction (RTJ), was the first directly-observed hydrothermal field in the Indian Ocean (Gamo et al. 2001). The KHF is a blacksmoker-type high temperature field, but fluids have an unusually high concentration of $\mathrm{H}_{2}(2.5-8.5 \mathrm{mmol} / \mathrm{kg})$, despite similarities to typical basalt-hosted mid-ocean ridge hydrothermal fluids in its other mineral and gas element compositions (Van Dover et al. 2001; Gallant and Von Damm 2006; Kumagai et al. 2008). Takai et al. (2004) proposed that the Kairei ecosystem is sustained by the primary production of hydrogenotrophic, hyperthermophilic methanogens, utilizing $\mathrm{H}_{2}$ and $\mathrm{CO}_{2}$ as primary energy and carbon sources.

The Edmond field is another high-temperature hydrothermal field located $160 \mathrm{~km}$ north of the KHF in the southern CIR (Van Dover et al. 2001). The $\mathrm{H}_{2}$ concentration in the Edmond fluid is markedly low, and in the range of typical basalt-hosted hydrothermal fluids (Gallant and Von Damm 2006; Kumagai et al. 2008).

Corresponding to a water-column hydrothermal signal discovered as early as the late eighties and recently (Jean-Baptiste et al. 1992; Kawagucci et al. 2008), two new areas of hydrothermal activity with associated chemosynthetic fauna were newly discovered in 2009 on the CIR at 18-20 ${ }^{\circ} \mathrm{S}$ (Nakamura et al. 2012). The Solitaire hydrothermal field extends over an area measuring approximately
$50 \times 50 \mathrm{~m}$, which is comparable to the areas of the KHF and Edmond fields. Several black smoker discharges have been observed, while most of the hydrothermal emissions are clear fluids. The fluid of the Solitaire field is characterized by a high $\mathrm{pH}\left(4.8\right.$ measured at $25{ }^{\circ} \mathrm{C}$ and $1 \mathrm{~atm})$ and $\mathrm{K} / \mathrm{Cl}$ ratio, compared to those of typical basalthosted hydrothermal fluids (Nakamura et al. 2012). The $\mathrm{H}_{2}$, $\mathrm{CH}_{4}$ and $\mathrm{CO}_{2}$ concentrations are within the range of typical basalt-hosted hydrothermal fields, and the biomass and taxonomical richness of the faunal communities are high.

Another new field, the Dodo hydrothermal field, exists $140 \mathrm{~km}$ away from the Solitaire field. In 2009, the fluid emissions were observed within an area covering approximately $15 \mathrm{~m}$ in diameter, and high temperature black fluid sprouted directly from cracks in the basaltic sheet lava without the formation of mounds. The concentration of $\mathrm{H}_{2}$ in the Dodo fluids is notably high $(>2 \mathrm{mmol} / \mathrm{L})$, while those of $\mathrm{CH}_{4}$ and $\mathrm{CO}_{2}$ are comparable with typical hydrothermal fluids. The $\mathrm{K} / \mathrm{Cl}$ ratio is also high, and comparable with that of the fluid from Solitaire field. In 2009, only a few hydrothermal vent animals were observed, unlike activity in the Solitaire field. When the Dodo field was revisited in 2013, it was found that the fluid emissions had ceased almost entirely (Kawagucci, Pers. Comm.).

In this chapter, we present the general geological background of these four hydrothermal fields along the CIR and discuss how the tectonic setting constrains hydrothermalism in each site. A summary of the geology, fluid chemistry, and faunal communities for each site is described in Nakamura (Chap. 12), and a detailed description of the rock samples is presented in Sato et al. (Chap. 13) and Morishita et al. (Chap. 14).

\subsection{Regional Setting}

The Central Indian Ridge (CIR) is a slow- to intermediaterate spreading system bounding the Somalia, the India, and Capricorn Plates. The full spreading rate ranges from $23 \mathrm{~mm} /$ year at $10^{\circ} \mathrm{N}$, to $47 \mathrm{~mm} /$ year at $25^{\circ} \mathrm{S}$ (MORVEL: DeMets et al. 2010) and the ridge axis is characterized by an axial valley. The CIR meets the Southwest Indian Ridge and the Southeast Indian Ridge at its southern end, forming a ridge-ridge-ridge triple junction (Rodriguez Triple Junction: RTJ). In the southern CIR, the ridge axis trends in an almost NNW-SSE direction and is segmented by several transform faults and non-transform offsets (Parson et al. 1993; Briais 1995). Briais (1995) describes the detailed axial bathymetry between the RTJ and $20^{\circ} 30^{\prime} \mathrm{S}$, and defines the axial segmentation using a sequential numbering system that increases northward starting at the RTJ. In accordance with this paper, we follow the nomenclature of ridge segments and use the prefix CIR-Sx (Fig. 11.1). 


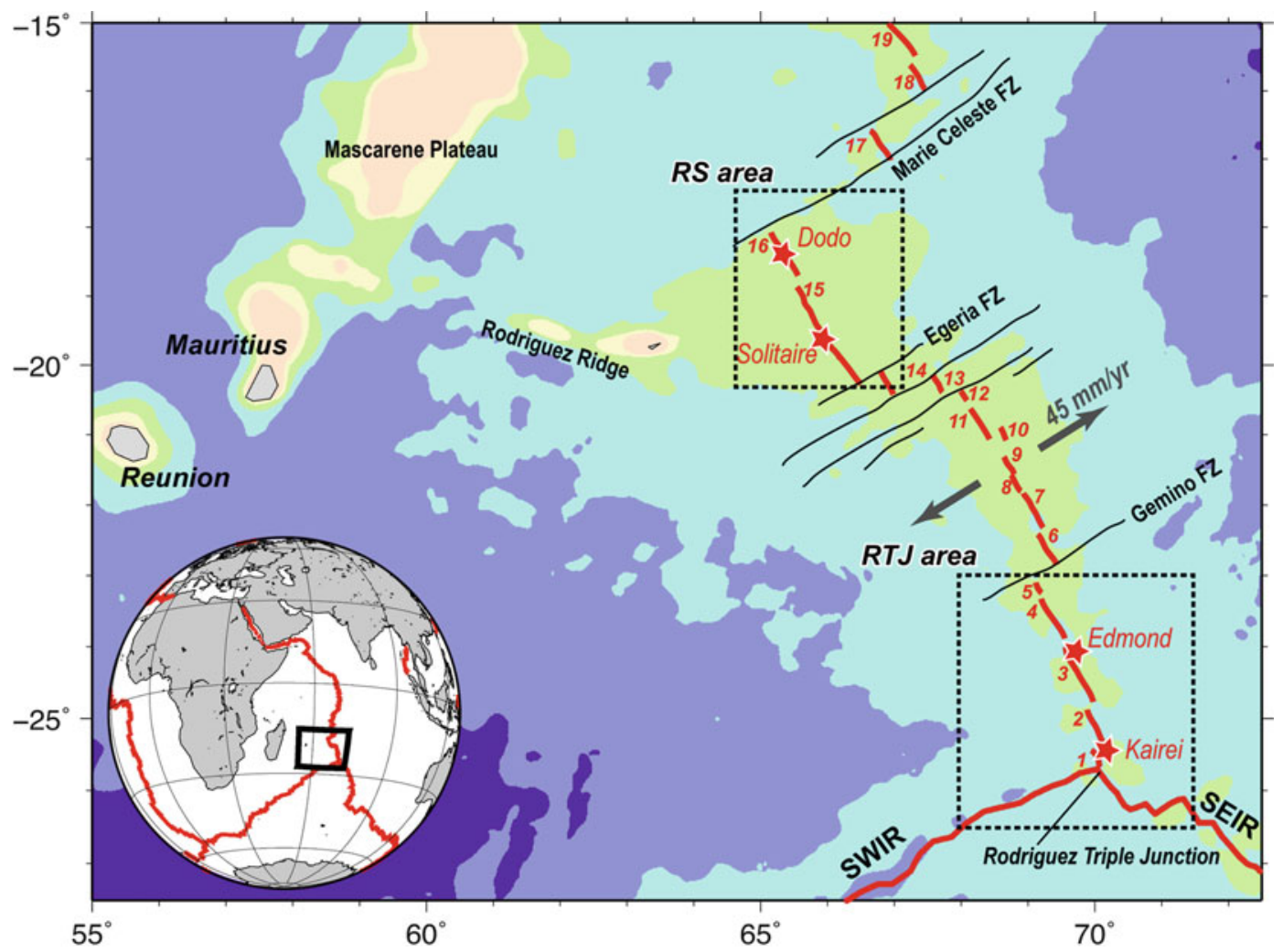

Fig. 11.1 Index map of the Central Indian Ridge (CIR) and adjacent area. Thick red lines with numbers indicate segments cited in the text. Red stars show the locus of hydrothermal fields. Two boxes indicate the areas shown in Figs. 11.2, 11.4, 11.5, and 11.6

The CIR axis gradually shifts westward from CIR-S1 to CIR-S15/S16 and then largely offsets eastward at the Marie Celeste Fracture Zone between CIR-S16 and S17 and further north (Fig. 11.1). CIR-S15 and S16, sometimes known as the Rodrigues Segment (RS), are sandwiched between the Egeria and Marie-Celeste Fracture Zones and both the on- and off-axis areas are shallower than the adjacent normal segments. The unusual elevated and smooth bathymetry, and the geochemical and geophysical characteristics, suggest a hotspot influence on ridge processes, although the Reunion hotspot is presently located 1,000 km away from the CIR (Mahoney et al. 1989; Murton 2005; Nauret et al. 2006; Füri et al. 2011). The Rodrigues Ridge, an WNW-ESE trending volcanic feature (Fig. 11.1), is considered to connect the Reunion-Mauritius hotspot track to the current CIR axis (e.g., Morgan 1978; Dyment et al. 2007).

\subsection{Data and Method}

\subsubsection{Rodriguez Triple Junction (RTJ) Area}

Geophysical data were collected during Japanese research cruises KH-93-3, KR00-05, YK01-15, YK05-16, YK09-13, and KH-10-6, from 1993 to 2000. The survey lines are mainly perpendicular to the ridge axis and extend off-axis by $50 \mathrm{~km}$. We compiled all available multibeam bathymetry data to create $50-\mathrm{m}$ grid data. Total geomagnetic field intensity and shipboard gravity data were also obtained along most of the survey lines. We calculated the magnetic anomaly by subtracting the appropriate International Geomagnetic Reference Field models, and then estimated the equivalent magnetization using the three-dimensional inversion method of (Parker and Huestis 1974; Macdonald et al. 1980), assuming a 500-m-thick magnetized layer. We also calculated the free-air gravity anomaly, and then estimated the Mantle Bouguer anomaly by subtracting the predicted gravity effects of the seafloor relief and a $6-\mathrm{km}$ thick crust from the free-air gravity anomaly (Kuo and Forsyth 1988). Rock samples were also collected along the neo-volcanic zones within the axial valley and on some anomalous off-axis topographic highs, using dredge hauls and submersible dives.

\subsubsection{Rodrigues Segment (RS) Area}

Bathymetry data were mainly collected during the KH-06-4 cruise and additionally during the cruise of YK13-9. 
The off-axis area, located within $50 \mathrm{~km}$ from the axis, is covered in CIR-S16, whereas the off-axis coverage is limited in amounts of CIR-S15. We created a 50-m gridded bathymetry for the whole area, and a more precise 25 -m grid around two hydrothermal fields. We obtained the total magnetic intensity data mostly along the axial valley, that is not enough to discuss the regional tectonics and calculate the spreading rate. The vector magnetometer data and shipboard gravity data were collected in two cruises but we did not fully analyze the data in TAIGA project. Therefore these are not referred to in this paper. Rock samples were collected along the neo-volcanic zone, using dredge hauls, rock cores, and submersible dives.

\subsection{Rodriguez Triple Junction (RTJ) Area}

\subsubsection{Morphology and Segmentation}

Figure 11.2 exhibits the compiled shaded bathymetry map of the Rodriguez Triple Junction (RTJ) area. The presentday ridge axis between the RTJ and $23^{\circ} \mathrm{S}$ consists of four

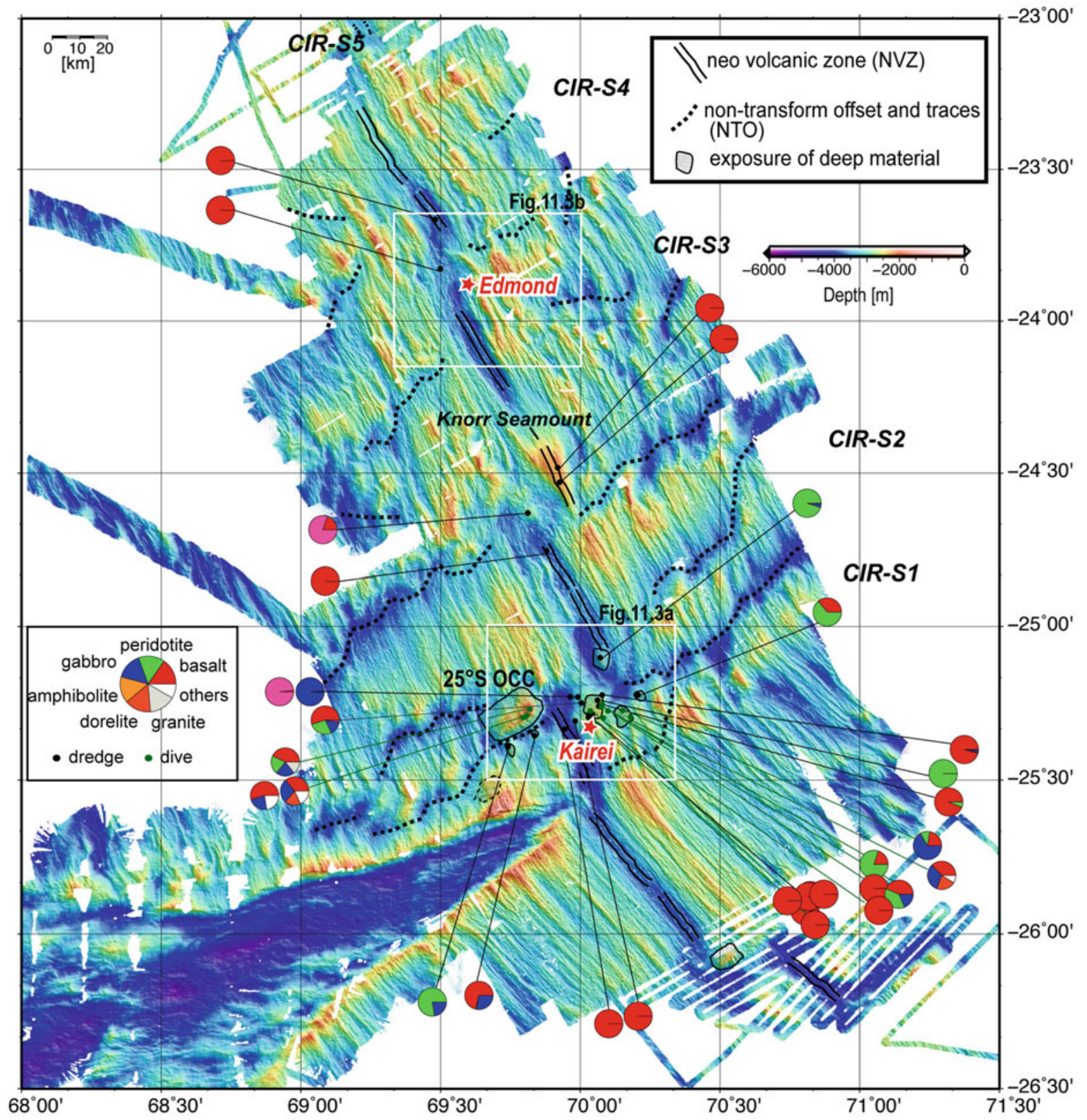

Fig. 11.2 Shaded bathymetry map of the RTJ (Rodriguez Triple Junction) area. Neo-volcanic zone and non-transform offsets are identified for each segment. Both the Kairei and Edmond hydrothermal fields (red stars) are located on the axial rift-valley wall. Pie diagrams show lithological proportions from dredge and dive collections. Two white boxes indicate the areas shown in Fig. 11.3 
Fig. 11.3 Detailed bathymetry map around the (a) Kairei; and (b) Edmond, hydrothermal fields. Dotted circles are anomalous domed highs near the boundary between CIR-S1 and S2. White stars indicate the locations of past NTO massifs where ultramafic rocks were recovered
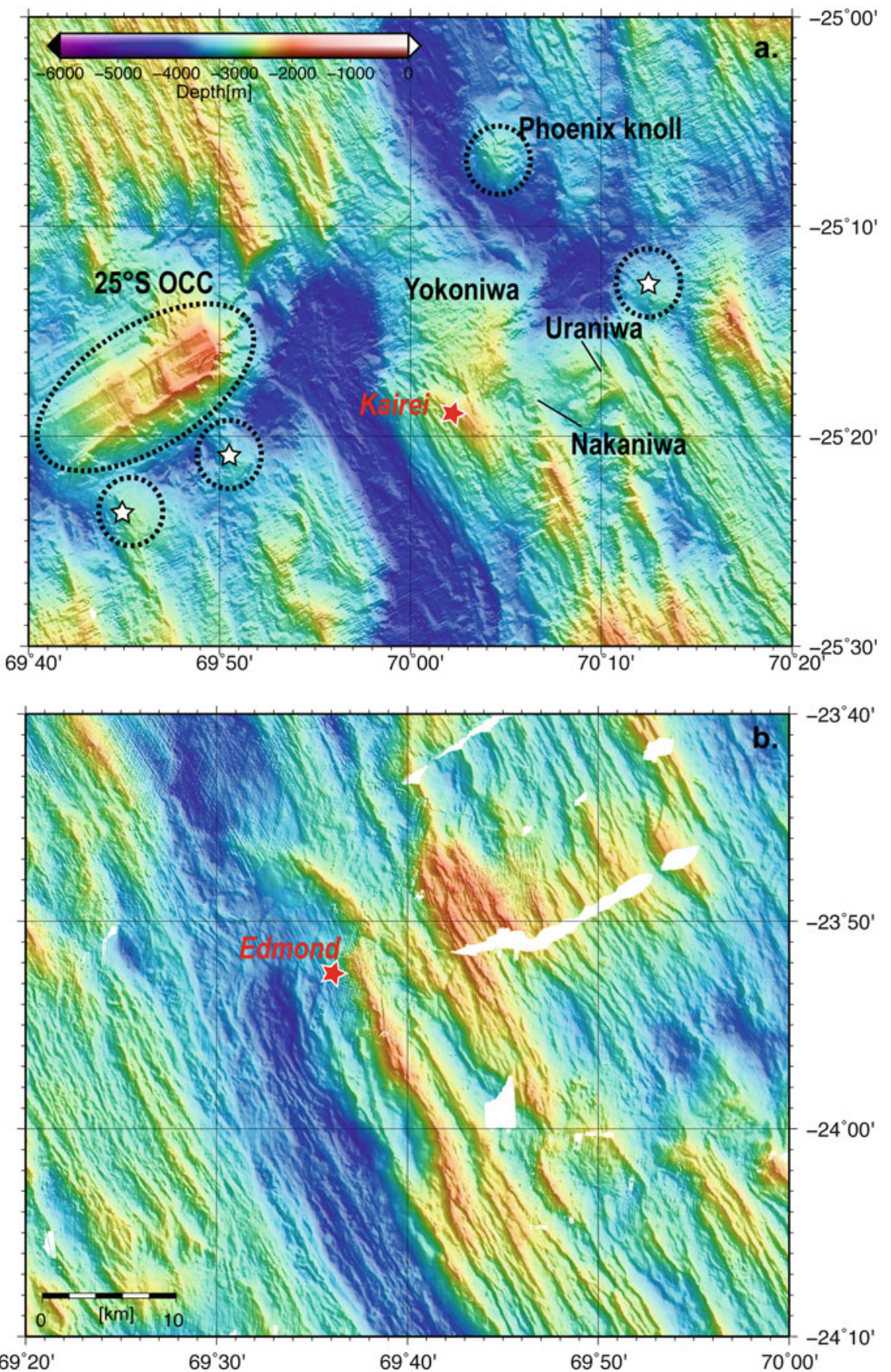

second-order segments. There is no transform fault in this area and the segments CIR-S1 to S4 are right lateral offset by non-transform discontinuities (NTDs). The axial valley develops at the ridge crest and numerous small, undeformed volcanic cones and flat-topped small volcanic knolls form a neo-volcanic zone.

CIR-S1 is a 20-km segment with a deep axial valley. In contrast to the typical axial morphology, the off-axis area of this segment is highly anomalous. The ridge-parallel abyssal hill pattern is disturbed and several domed highs are distributed along the trace of the NTD between CIR-S1 and S2 (Fig. 11.3a). We recovered deep crust and/or mantle materials on most of these anomalous highs, and interpreted them as modern and remnant NTO (non-transform offset) massifs or oceanic core complexes. They are closely related to the origin of the Kairei hydrothermal field (KHF), and we describe details in Sect. 11.4.4. The segment length shortens, in the farther off-axis, suggesting that the CIR-S1 was newly 


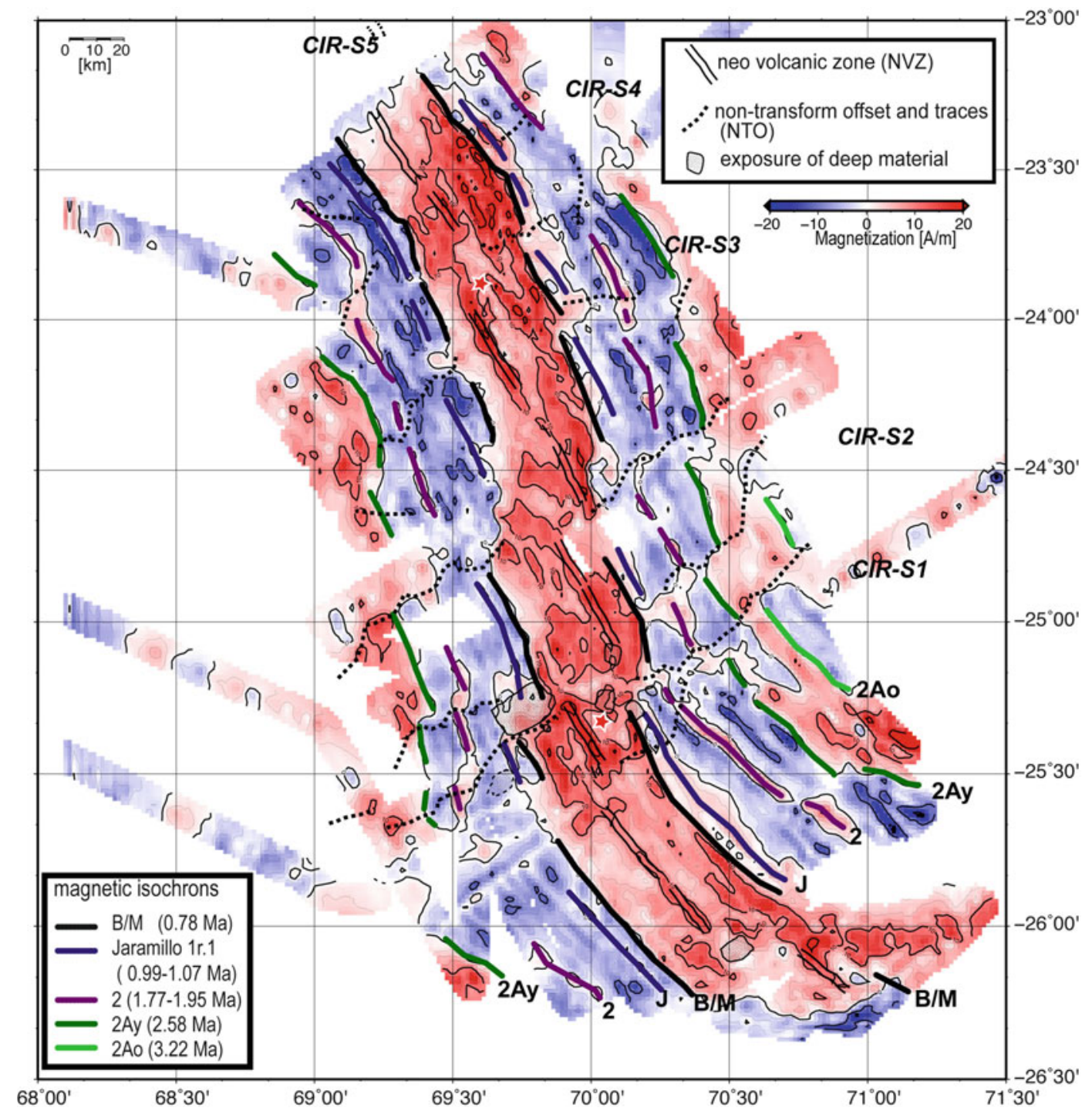

Fig. 11.4 Distribution of magnetization in RTJ area. Contour interval is every $2.5 \mathrm{~A} / \mathrm{m}$. Identified magnetic isochrones are superimposed

created during the evolution of the triple junction (Munschy and Schlich 1988; Honsho et al. 1996; Mendel et al. 2000).

CIR-S2 is offset $34 \mathrm{~km}$ eastward from CIR-S1. The shallow axial depth around $24^{\circ} 50^{\prime} \mathrm{S}$ and the concentration of volcanic cones suggest mantle upwelling occurs here. The axial valley appears asymmetric, suggesting a recent jump of neo-volcanic zone eastwards. A unique domed high is located within the southern end of the axial valley, where we recovered fresh and altered peridotite samples (Phoenix knoll in Fig. 11.3a). The off-axis morphology clearly shows that CIR-S2 consisted of two segments in the past. The southern segment progressively shortened and finally vanished, whereas the northern segment lengthened at its expenses. Gac et al. (2006) modeled such a shortening and lengthening of ridge segments. A typical oceanic core complex, the $25^{\circ} \mathrm{S}$ OCC, was formed in the final phase of the southern segment (Morishita et al. 2009; Sato et al. 2009).

CIR-S3 also shows an anomalous feature at the southern end of the axial valley, where it is filled by the Knorr Seamount, a large triangular-shaped volcano measuring nearly $40-\mathrm{km}$ long (Fig. 11.2). This seamount is volcanic, and a set of parallel rifts has developed at its summit. The off-axis morphology indicates that the segment was also made of two segments in the past, like CIR-S2. The abyssal hill pattern is not symmetric and the magmatic activity appears to be highly variable, particularly in the southern end.

CIR-S4 is only slightly offset from CIR-S3. The axial valley narrows and shallows toward the segment center at 
$23^{\circ} 20^{\prime} \mathrm{S}$, like a typical slow-spreading ridge segment (e.g., Sempéré et al. 1993), suggesting three dimensional mantle upwelling (Lin et al. 1990). Despite the insufficient off-axis coverage, the abyssal hills are shallower in the eastern off-axis near the current segment center.

\subsubsection{Magnetics and Gravity}

Based on the estimated magnetization distribution (Fig. 11.4), we identified Brunhes/Matuyama (B/M) boundaries $(0.78 \mathrm{Ma})$, the Jaramillo subchron (Chron 1r.1, 0.99-1.07 Ma), Chron 2 (1.77-1.95 Ma) and young and old boundaries of Chron 2A (2.58-3.22 Ma). Chron 2Ao (old) is only recognized in the eastern off-axis of CIR$\mathrm{S} 1, \mathrm{~S} 2$, and in the northernmost segment of SEIR. The neovolcanic zone in each segment is accompanied by high magnetization stronger than $10 \mathrm{~A} / \mathrm{m}$. The neo-volcanic zone of CIR-S1 lies at the center of a positive magnetization zone bounded by the $\mathrm{B} / \mathrm{M}$ boundaries. In contrast, the neo-volcanic zone with the highest magnetization deviates easterly in CIR-S2, and westerly in CIR-S3 and S4. This observation suggests a recent jump of the volcanic center. In support of this idea, another high magnetization zone is also situated between the eastern $\mathrm{B} / \mathrm{M}$ boundary and the neo-volcanic zone in CIR-S3 and S4.

The calculated full-spreading rate is $48.5 \mathrm{~mm} / \mathrm{year}$ in the studied area on average, which is comparable to that of $47 \mathrm{~mm} /$ year as predicted by the global plate model (DeMets et al. 2010). A spreading asymmetry is observed for all segments. In CIR-S1, there is no significant difference between our interpretation and that proposed by Mendel et al. (2000). The identification of magnetic isochrones suggests that CIR-S1 was created in ca. Chron 2Ay (2.58 Ma). The off-axis morphology in the northern three segments suggests that the segments each consisted of two segments in the past. Magnetic isochrones support this interpretation, for the isochrones are slightly offset or discontinuous at the traces of the NTDs. Although the exact timing of the amalgamation of the segments differs among the segments, the southern CIR was highly segmented before $1 \mathrm{Ma}$. This may suggest a change in the mantle upwelling scheme in this region.

The residual mantle Bouguer anomaly map (RMBA, Fig. 11.5) shows a remarkable difference between segments. CIR-S1 is characterized by a high RMBA of around $30 \mathrm{mGal}$ in the off-axis area. This suggests a thin crust and/or a dense material beneath the seafloor, supporting the idea of meltstarved, tectonism dominant, spreading processes. It is also consistent with the existence of an oceanic core complex and other topographic highs with exhumation of mantle materials. The RMBA in CIR-S2 is generally higher in the southern part, and the $25^{\circ} \mathrm{S}$ oceanic core complex accompanies a very high RMBA. The RMBA is also high at the southern segment end of the present-day ridge axis. CIR-S3 shows a low RMBA along the axial valley. Although we cannot deny the possibility of an inappropriate estimation of plate cooling, we prefer the interpretation that the crust is thicker beneath the Knoll Seamount and recent CIR-S3, and in support of this the abyssal hill morphology also suggests recent robust magmatism in this area. The trace of NTD between CIR-S3 and S4 is clearly accompanied by a high RMBA, suggesting a thinner crust along the segment boundary. CIR-S4 shows relatively a lower RMBA than other segments and clear along-axis variation of RMBA. Although we do not have enough data for the northern segment end, CIR-S4 is a magmatically active slow-spreading type segment, where the mantle upwells at the segment center.

\subsubsection{Kairei Hydrothermal Field and Surroundings}

The Kairei Hydrothermal Field (KHF) is located about $7 \mathrm{~km}$ east of the neo volcanic zone of CIR-S1, on the eastern riftvalley wall (Fig. 11.3a). Due to the presence of a couple of normal faults, the rift-valley wall shows a step-like morphology, and the KHF is located $1,700 \mathrm{~m}$ higher than the valley floor on one of these steps. Although the KHF is developed on a typical ridge-parallel structure, the unusual geological features suggest that tectonism-dominant ridge processes spread over the boundary between CIR-S1 and S2.

An anomalous domed high with a corrugated surface was first reported northwest of a deep nodal basin in the northern

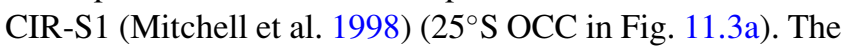
survey that followed revealed less-deformed serpentinized peridotite exposed on the steep inward slope, and highly deformed rocks widely distributed on the top (Morishita et al. 2009). This observation, and the higher gravity anomaly, support the idea that this domed high is an oceanic core complex (OCC) exposed along a detachment fault. A detailed magnetic analysis showed that the oceanic core complex, known as $25^{\circ} \mathrm{S} \mathrm{OCC}$, was initiated at the southern inside corner of CIR-S2 during the Matsuyama reversal polarity chron (Sato et al. 2009).

We also discovered another OCC, about $15 \mathrm{~km}$ east of the KHF (Fig. 11.3a). Known as Uraniwa Hills, this OCC consists of two domed highs (Kumagai et al. 2008): the northern hill is a rectangular-shaped dome, whereas the southern hill is a more elongated massif with corrugations on the surface. A prominent breakaway ridge bounds the eastern end of this massif. Troctolites and olivine gabbros were sampled at Uraniwa Hills, in addition a dunite (Morishita et al. 2009; Nakamura et al. 2009). A NW-SE trending minor ridge (Nakaniwa Ridge in Fig. 11.3a) 


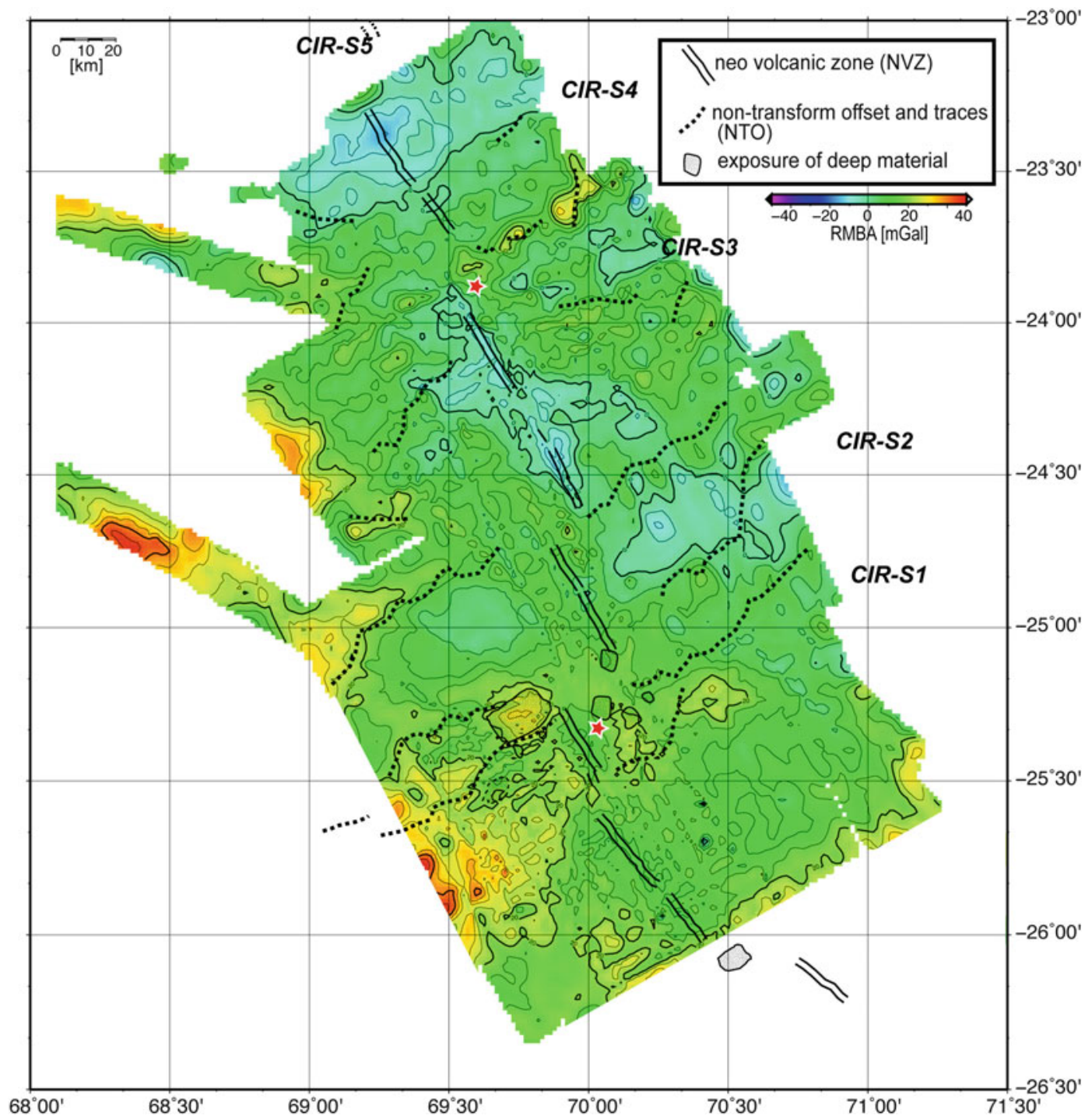

Fig. 11.5 Residual mantle Bouguer anomaly variation of RTJ area. Contour interval is $5 \mathrm{mGal}$

where gabbroic rocks were also recovered is situated between the Uraniwa Hills and the abyssal hills where the KHF develops.

We observed two deep nodal basins at both the northern segment end of CIR-S1 and at the southern segment end of CIR-S2. Between the two nodal basins, a shallow domedlike massif, has developed. It is $1,700 \mathrm{~m}$ high from the rift valley floor and lies oblique-to-parallel to the ridge. High RMBA (Fig. 11.5) and the peridotite exposure on the surface, indicate a very thin magmatic crust beneath this massif and the tectonism-dominant extension of the area. Similar massifs are often observed at NTDs along the Mid-Atlantic Ridge and, are known as NTO (non-transform offset) massifs. Low-angle detachment faults are likely to be the mechanism for the exhumation of deep materials at NTO massifs (Eulalia et al. 2000). The Rainbow and Saldanha hydrothermal sites are located at NTO massifs, where serpentinized peridotite hosts the hydrothermal system supplying hydrogen-rich fluid (Eulalia et al. 2000; Miranda et al. 2003). We named the NTO massif between CIR-S1 and S2 Yokoniwa Rise. During the recent submersible dive, relatively fresh inactive hydrothermal chimneys were discovered on the top. Although the dense CTD tow-yo surveys could not detect any hydrothermal plume anomaly around Yokoniwa, an ultramafic-hosted hydrothermal system probably existed in the recent past.

The Yokoniwa Rise is a current NTO massif, but we also recognized past NTO massifs along the NTD trace between CIR-S1 and S2. One of them is located just south of the $25^{\circ} \mathrm{S}$ OCC where Hellebrand et al. (2002) reported the exposure of mantle peridotites. The other smaller massifs (white stars in Fig. 11.3a) are also accompanied by ultramafic rocks on the surface, suggesting a common origin of NTO massifs. 
Another unusual massif, hereafter known as Phoenix knoll, is located within the axial valley floor of CIR-S2 (Fig. 11.3a). This massif is $\sim 6 \mathrm{~km}$ in diameter, with a steeper slope on its western side. We tentatively recognized an ambiguous surface corrugation on the top, but cannot completely deny the possibility of artifact. The dredged samples are mostly serpentinized peridotites. The formation process of the Phoenix knoll is still discussed: Morishita et al. (Chap. 14) propose serpentinite diapirism, whereas the asymmetric structure with its corrugated surface supports the hypothesis of a detachment fault. Ridge-parallel fault scarps cut the massif on its northern slope and undeformed volcanic knolls adjoin the massif. These observations indicate that the segment is now under a normal magmatic spreading phase. The chaotic structure at the current segment boundary and along the NTD trace, strongly suggests an important temporal and spatial variation of the melt supply in this area.

\subsubsection{Tectonic Evolution and Hydrothermalism}

The hydrothermal fluid of the KHF is unique in its high $\mathrm{H}_{2}$ and low $\mathrm{CH}_{4}$ contents (Van Dover et al. 2001; Gallant and Von Damm 2006; Kumagai et al. 2008). In general, the high content of $\mathrm{H}_{2}$ in the hydrothermal fluid is explained by the generation of $\mathrm{H}_{2}$ through the serpentinization of ultramafic rocks. Methane is also a product of a series of the serpentinization process, so most $\mathrm{H}_{2}$ rich hydrothermal fields spout both high $\mathrm{H}_{2}$ and high $\mathrm{CH}_{4}$ fluids and are located above the exposure of ultramafic rocks due to tectonic extension. The $\mathrm{KHF}$ is just on the ridge-parallel volcanic knoll and is surrounded by basalt lava flows. However, ultramafic rocks are widely exposed around the KHF. Nakamura et al. (2009) proposed that the interaction of seawater with troctolites beneath the Uraniwa Hills explains the composition of the KHF fluids. Their theoretical model predicts that the high $\mathrm{H}_{2}$, low $\mathrm{CH}_{4}$, and high Si contents of the KHF fluid can be attributed to serpentinization of the troctolites and the subsequent hydrothermal reactions with basaltic wall rocks under the KHF. Although such an idea explains the KHF fluid geochemistry, it is, however, rather hard to suppose a large scale, across axis circulation from the Uraniwa Hills to the KHF. It is considered likely that a detachment fault exhuming mantle materials on the surface continues to the shallow subsurface beneath the basaltic flow at the KHF, although the fault geometry has to be confirmed. The troctolites and/or other olivine-rich materials may exist in the shallow subsurface beneath the KHF, where the serpentinization process goes on, closely related to the detachment faulting. The relatively high RMBA beneath the KHF supports this idea. The vents of the KHF appear to stand at the foot of an inward facing normal fault scarp. It is likely that the surface normal faults control the position of the upward fluid flow, and that the circulation is driven by the magmatic heat of the neo-volcanic zone. The KHF differs from both the "magma-driven" basalt-hosted hydrothermal fields and the "tectonic-controlled" ultramafic-hosted fields. It is in another category, and is, a magma-assisted, ultramafic hosted, hydrogen-rich hydrothermal system (hydrogen TAIGA).

The Edmond hydrothermal field, located near the northern end of CIR-S3, is similar in that the vent site is located on the eastern rift-valley wall near the NTD (Fig. 11.3b). However, the fluid shows a typical sulfur-rich content, and there is no evidence of ultramafic exposures around the Edmond field (Van Dover et al. 2001; Gallant and Von Damm 2006; Kumagai et al. 2008). Unlike the other hydrothermal fields on fast-spreading ridge, the Edmond filed is not directly linked with the neo-volcanic zone, and the upward fluid path may be controlled by the normal faults of the riftvalley. It is likely that this explains the longevity of the hydrothermal activity (Van Dover et al. 2001), because the circulation path has been constrained by the fault system. The Edmond field is a sulfur-rich hydrothermal system (sulfur TAIGA), hosted by basalt lava and driven by the magmatic heat of the ridge axis, and its circulation path is tectonically controlled.

\subsection{Rodrigues Segment (RS) Area: CIR 18-20'S}

\subsubsection{Morphology and Segmentation}

Figure 11.6 exhibits the compiled shaded bathymetry map of the Rodrigues Segment (RS) area. This area is located on the westernmost of the current CIR axis, and is close to the Rodrigues Ridge. The axis is offset by the Marie Celeste Fracture Zone at its northern end, and by the Egeria Fracture Zone at its southern end. Between these two transform faults, the axial valley is relatively continuous. In this area, we were able to define two segments, CIR-S15 and S16, because it was possible to trace the boundary of these segments in the off-axis area. CIR-S15 is a segment measuring $~ 150-\mathrm{km}$ long, and the axial valley bends at three points. We tentatively named the four parts, CIR-S15A to -S15D.

CIR-S15A shows a slow-spreading ridge morphology, with deep axial valley and well-ordered off-axis abyssal hills. We can easily recognize the continuous neo-volcanic zone at the center of the axial valley. CIR-S15B has an hourglass-shaped axial valley, where the rift-valley narrows toward the center. The axial valley is shallower than in the other parts, suggesting a higher melt supply. The rift-valley wall is extremely asymmetric: the eastern wall consists of steep normal faults and the western side 
Fig. 11.6 Shaded bathymetry map of the RS (Rodriguez Segment) area. The pale colored bathymetry data were collected by previous French cruises (Dyment et al. 1999). Newly discovered Solitaire and Dodo hydrothermal fields are located in a volcanically active zone (red stars). Two black boxes indicate the areas shown in Fig. 11.7

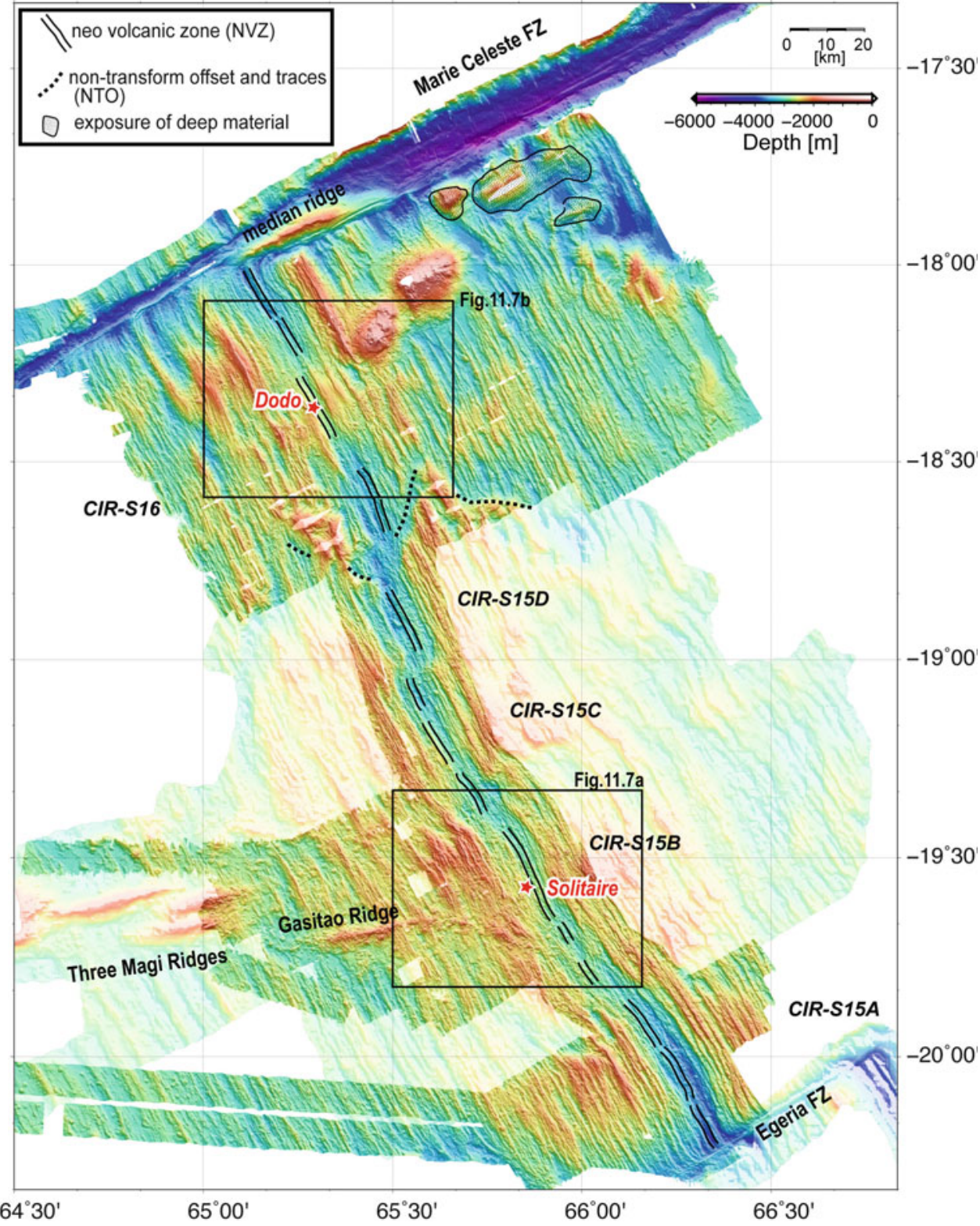

center, suggesting that $\mathrm{S} 15 \mathrm{C}$ is magmatically active at present.

CIR-S16 also shows recent vigorous volcanism. The typical neo-volcanic zone consisting of hummocks and aggregated hummocks (Fig. 11.7b), is developed near the segment ends; the axial depth becomes shallow toward the segment center, where smooth, flat sheet-flow lava buries the whole rift-valley floor. The latter morphology resembles that observed in the fast-spreading ridge crest, suggesting a higher melt supply. The off-axis area is much more anomalous. We discovered a large off-axis seamount east of CIR-S16, with diameter of 15-20 km and a summit depth shallower than $700 \mathrm{~m}$. It is clear that the seamount erupted in the off-axis area, because the volcanic materials cover the underlying abyssal hill fabric and no 
Fig. 11.7 Detailed bathymetry map around the (a) Solitaire and (b) Dodo hydrothermal fields
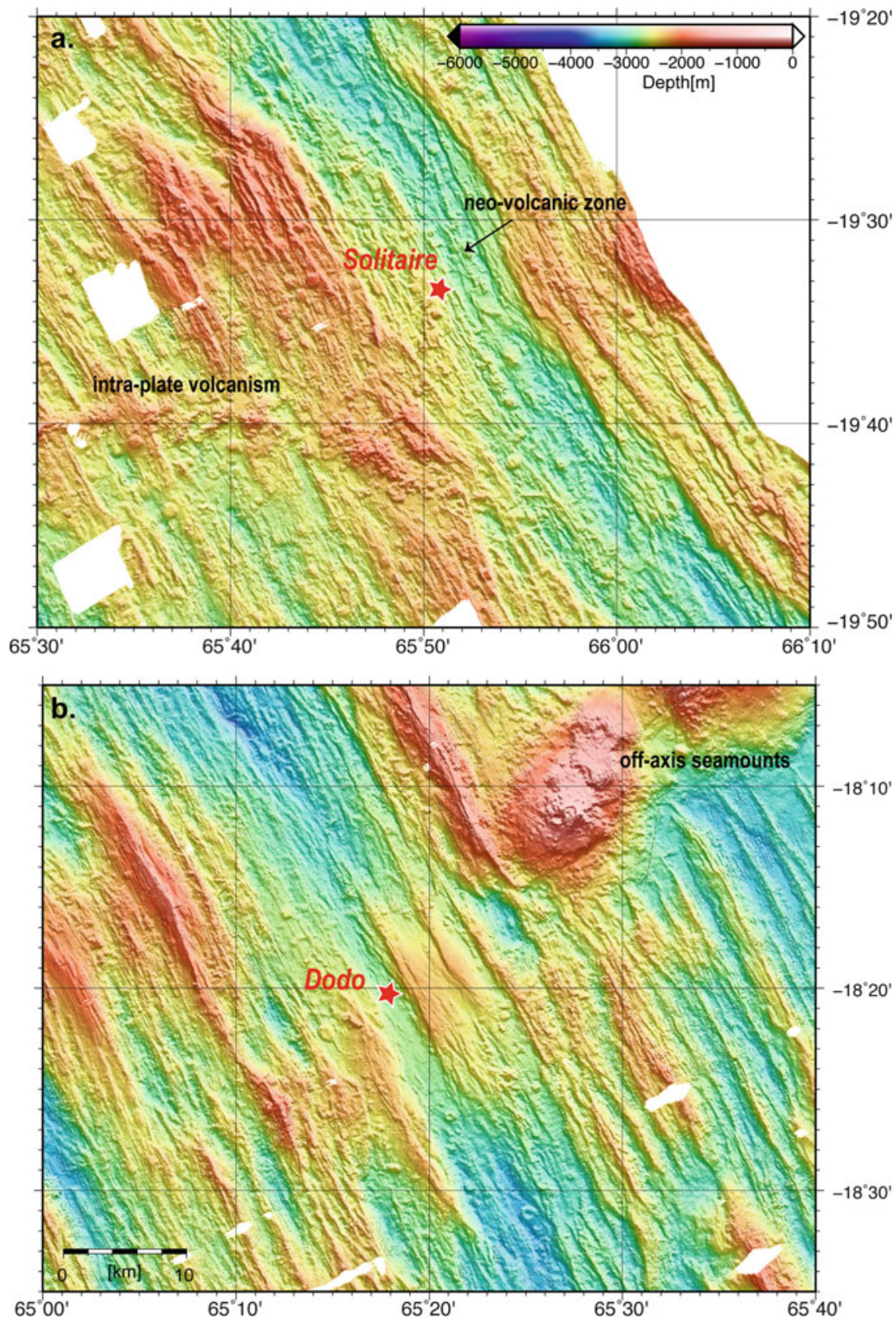

ridge-parallel normal faults deform them. Similar large offaxis seamounts, the Lamont Seamounts, have been discovered on the East Pacific Rise near to long-offset transform faults (Fornari et al. 1988), with a magmatically-active nearby ridge segment (Scheirer and Macdonald 1995). This similarity suggests that a long-offset transform fault may play a key role in transferring water from the seafloor to underneath the mantle, promoting melting. East of the offaxis seamounts we identified a few dome-like (or elongated) highs, with flow-line parallel corrugations on their tops. Although no rock samples were recovered from these massifs, they are interpreted to be oceanic core complexes, where the melt supply is limited and the mantle materials are exhumed along detachment faults. This observation suggests that the temporal variation of melt supply is very large in northern CIR-S16.

\subsubsection{Rock Geochemistry}

The RS area has been studied as a case of distal hotspotridge interaction. The Rodrigues Ridge, Three Magi Ridge and Gasitao Ridge topographically connect the Reunion hotspot track and the CIR and the RS area shows relatively shallow depths suggesting higher melt supply. However the origin of these intra-plate ridges and the style of distal 
hotspot-ridge interaction are still the subject of debate. Some previous studies (Mahoney et al. 1989; Murton 2005) proposed that a northward enrichment of incompatible elements and radiogenic isotopes within the basalts in CIR-S15 and S16 suggest the inflow of channelized plume material supplied from the Reunion hotspot. Nauret et al. (2006) showed that $\mathrm{Pb}$ isotopes become more radiogenic from south to north, and incompatible trace elements become more enriched, but the composition of Reunion lavas is not a suitable end member for the $\mathrm{Pb}$ isotope and $\mathrm{Ba} / \mathrm{Nb}$ trend. They concluded that the geochemical trend seen along the ridge axis is not related to Reunion-type plume material and the geochemical anomaly on the RS area is a result of mixing of the Reunion plume and depleted mantle. However, their argument is based on only one sample obtained from CIR-S15B. Machida et al. (in press) analyzed a lot of basalt samples from CIR-S15 and S16, and proposed that two melt components mainly control the geochemical signature: a radiogenically enriched component characterized by the Rodrigues Ridge or intermediate series of Mauritius island, and a radiogenically depleted component characterized by the Gasitao Ridge. Their results suggest that the mantle heterogeneity can explain the geochemical anomaly of the RS area but this does not require a channelized plume flow expected from the morphology. Cordier et al. (2010) reported the occurrence of ancient lavas enriched in incompatible elements distributed symmetrically on either side of the ridge whereas on-axis samples are typical N-MORB, using on- and off-axis basalt samples collected across CIR15B. They proposed that the geochemical variations of zero-age basalts may primarily reflect periodic processes rather than the spatial distribution of mantle heterogeneities. Füri et al. (2011) reported significantly higher ${ }^{3} \mathrm{He} /{ }^{4} \mathrm{He}$ rations between $19^{\circ}$ and $20^{\circ}$ along the axis, as well as along the Gasitao Ridge, Three Magi Ridges and Rodrigues Ridge, consistent with lateral flow of hot spot mantle from Reunion toward the CIR. However, basaltic lavas sampled at CIR-15B axis, i.e., the intersection of the CIR and the off-axis volcanic structures, show typical N-MORB-like trace element ratios.

\subsubsection{Tectonic Background of Hydrothermal Fields}

Two hydrothermal fields were discovered in the RS area in 2009 (Nakamura et al. 2012). The Solitaire field (in CIR$\mathrm{S} 15 \mathrm{~B}$ ) has been observed to consist mainly of clear smokers with high $\mathrm{pH}$ (4.8 measured at $25^{\circ} \mathrm{C}$ and $\left.1 \mathrm{~atm}\right)$ fluids and a rich faunal community. The Dodo field (in CIR-S16) is characterized by high temperature $\left(356{ }^{\circ} \mathrm{C}\right.$ at a maximum), and $\mathrm{H}_{2}$ rich fluids $(>2 \mathrm{mmol} / \mathrm{L})$ spout directly from cracks in the basalt sheet lava.

The Solitaire field is located at the western flank of the CIRS15B segment center. It was first predicted by a hydrothermal plume anomaly surveyed in the late 1980s (Jean-Baptiste et al. 1992). As described in Sect. 11.5.1, the segment center shows a highly asymmetric structure. The western rift wall shows a gentle step-like morphology (Fig. 11.7a) and the Solitaire field has developed on the step. We also identified a number of volcanic cones on the step, and these are clearly different from the series of hummocks forming the neo-volcanic zone of the CIR axis. These volcanic cones on the step are undeformed and basalt samples with fresh glass were recovered from one of these cones, supporting the idea that the volcanism has recently occurred. Basalts from the neo-volcanic zone range from 8-53 and 5-10 wt.\% in $\mathrm{SiO}_{2}$ and $\mathrm{MgO}$, respectively, and belong to the subalkaline rock series, whereas basalts from the volcanic cones on the step show higher $\mathrm{Na}_{2} \mathrm{O}$ and total alkali compositions (Machida et al. in press). They are considered to be a series of similar volcanic knolls extending from the Gasitao Ridge. These observations suggest that the Solitaire field is influenced by intra-plate volcanism related to the mantle plume or mantle heterogeneity.

The Dodo field, on the other hand, is located just on the neo-volcanic zone of CIR-S16, where smooth sheet-flow lava covers an area of about $70 \mathrm{~km}^{2}$ (Fig. 11.7b). The lava morphology suggests a high flux of eruption (Gregg and Fink 1995) which is typical of fast-spreading ridges, despite a relatively slow spreading rate (average full rate of $\sim 43 \mathrm{~km} /$ Myr). We recognized several fissures on the sheet lava. However, the distribution of vents does not seem to relate to these fissures. The Dodo field was first predicted by the plume anomaly in the water column in 2006 (Kawagucci et al. 2008), and then discovered in 2009 (Nakamura et al. 2012). When we revisited the field in 2013, the fluid venting has already stopped. This observation suggests that the heat supplied by dyke intrusion drives the short-lived hydrothermal circulation, and that the circulation then wanes as the lava cools. The plume anomaly from the Dodo field predicted a high content of hydrogen in the venting fluid (Kawagucci et al. 2008), and this was confirmed by fluid sampling (Nakamura et al. 2012). There are no signs of surface/shallow ultramafic rocks, nor deep-rooted faults, that are usually considered to provide rich hydrogen in hydrothermal fluid. Kawagucci et al. (2008) proposed that serpentinization extensively occurs due to the enormous amount of water supplied from the Marie Celeste fracture zone. However, this idea contradicts the shallow, small-scale circulation at the sheeted basalt sheet-flow, suggested by the geological setting. Although we have not yet understood this type of hydrothermal system, it is a clear illustration of the diversity of hydrogen-rich systems. 


\subsection{Summary}

Four hydrothermal fields along the Central Indian Ridge (CIR) are shown to have different characteristics in their fluid geochemistry and associated ecosystems. Geophysical mapping and rock sampling indicate that the different tectonic setting of each field cause the diversity amongst the hydrothermal systems A summary of the findings of each field is as follows:

1. The Kairei hydrothermal field at $25^{\circ} 19^{\prime} \mathrm{S}$ is located on the shoulder of the axial valley wall near the northern end of CIR-Seg1. High Bouguer gravity anomaly and the exposures of ultramafic rocks near the KHF suggest that the ultramafic rocks exist below a thin basaltic layer at the KHF. It is likely that the high- $\mathrm{H}_{2}$ and low- $\mathrm{CH}_{4}$ contents of the Kairei field are supported by both serpentinization of olivine rich rocks, and a reaction with basalt in the shallow subsurface. The vent site is located at the foot of an inward fault scarp, indicating that the upflow path is controlled by the fault, and it is considered likely that the axial magma drives the circulation.

2. The Edmond hydrothermal field at $23^{\circ} 52^{\prime} \mathrm{S}$, located on the shoulder of the axial valley wall at the northern end of CIR-Seg3, is also hosted by basalt. Although the location is similar to that of the Kairei field, no evidence of ultramafic exposure is recognized and the $\mathrm{H}_{2}$ and $\mathrm{CH}_{4}$ contents are within the typical range of MOR hydrothermal fluids.

3. The Solitaire field at $19^{\circ} 33^{\prime} \mathrm{S}$ is located about two miles away from the neo-volcanic zone of CIR-Seg15B. The area shows a unique volcanic environment, where typical MOR neo-volcanic zone activity and intra-plate volcanism coexist at a short distance. The Solitaire field is related to the mantle plume that originated from the Reunion hotspot or to the mantle heterogeneity in this area.

4. The Dodo field at $18^{\circ} 20^{\prime} \mathrm{S}$ is located at the center of the axial valley floor of CIR-Seg16. The axial valley of the segment center is covered by large-scale basaltic sheetflow lava, which is distinct from that of typical slow spreading ridges. The morphology and adjacent large off-axis seamounts support the idea that excess melt is supplied in this segment. It is likely that this anomalous magmatism is influenced by mantle plume or by a largeoffset transform fault just north of the segment. The concentration of $\mathrm{H}_{2}$ in the Dodo fluids is notably high, and this is quite atypical for a basalt-hosted hydrothermal system.

The large diversity found among the four known active hydrothermal fields along the southern CIR provides important insights on the tectonic and magmatic control of hydrothermal systems.
Acknowledgements We are grateful to the operation teams of the submersible SHINKAI 6500 and AUV r2D4, and to the crew of the R/ $V$ HAKUHO MARU and R/V YOKOSUKA, for their skilled and proficient acquisition of data. We also thank two reviewers to provide us many valuable comments. The authors wish to thank Prof. Urabe, and members of Project TAIGA, for their collaboration and useful discussions. This study was supported by the Ministry of Education, Culture, Sports, Science and technology (MEXT), Grant-in-Aid for Scientific Research on Innovative Areas "Project TAIGA: Transcrustal Advection and In-situ biogeochemical process of Global subseafloor Aquifer" (20109002).

Open Access This chapter is distributed under the terms of the Creative Commons Attribution Noncommercial License, which permits any noncommercial use, distribution, and reproduction in any medium, provided the original author(s) and source are credited.

\section{References}

Briais A (1995) Structural-analysis of the segmentation of the CentralIndian-Ridge between 20-degrees-30's and 25-degrees-30's (Rodriguez-Triple-Junction). Mar Geophys Res 17(5):431-467

Cordier C, Benoit M, Hemond C, Dyment J, Le Gall B, Briais A, Kitazawa M (2010) Time scales of melt extraction revealed by distribution of lava composition across a ridge axis. Geochem Geophys Geosyst 11. doi:10.1029/2010gc003074

DeMets C, Gordon RG, Argus DF (2010) Geologically current plate motions. Geophys J Int 181(1):1-80. doi:10.1111/j.1365-246X. 2009.04491.x

Dyment J, Gallet Y, The M. 2 Scientific Party (1999) The Magofond 2 cruise: a surface and deep-tow survey on the past and present Central Indian Ridge. InterRidge News 8(1):25-30

Dyment J, Lin J, Baker ET (2007) Ridge-hotspot interactions. Oceanography 20(1):102-115

Eulalia G, Charlou JL, Radford-Knoery J, Parson LM (2000) Non-transform offsets along the Mid-Atlantic Ridge south of the Azores (38 N-34 N): ultramafic exposures and hosting of hydrothermal vents. Earth Planet Sci Lett 177:89-103

Fornari DJ, Perfit MR, Allan JF, Batiza R, Haymon R, Barone A, Ryan WBF, Smith T, Simkin T, Luckman MA (1988) Geochemical and structural studies of the Lamont seamounts: seamounts as indicators of mantle processes. Earth Planet Sci Lett 89(1):63-83. doi:10. 1016/0012-821X(88)90033-7

Füri E, Hilton DR, Murton BJ, Hémond C, Dyment J, Day JMD (2011) Helium isotope variations between Réunion Island and the Central Indian Ridge $\left(17^{\circ}-21^{\circ} \mathrm{S}\right)$ : new evidence for ridge-hot spot interaction. J Geophys Res 116(B2):B02207. doi:10.1029/ 2010JB007609

Gac S, Tisseau C, Dyment J, Goslin J (2006) Modelling the thermal evolution of slow-spreading ridge segments and their off-axis geophysical signature. Geophys J Int 164(2):341-358. doi:10.1111/j. 1365-246X.2005.02844.x

Gallant RM, Von Damm KL (2006) Geochemical controls on hydrothermal fluids from the Kairei and Edmond Vent Fields, $23^{\circ}-25^{\circ} \mathrm{S}$, Central Indian Ridge. Geochem Geophys Geosyst 7(6):1-24. doi:10.1029/2005GC001067

Gamo T, Chiba H, Yamanaka T (2001) Chemical characteristics of newly discovered black smoker $£$ uids and associated hydrothermal plumes at the Rodriguez Triple Junction, Central Indian Ridge. Earth Planet Sci Lett 193:371-379

Gregg TKP, Fink JH (1995) Quantification of submarine lava-flow morphology through analog experiments. Geology 23(1):73. doi:10.1130/0091-7613(1995)023<0073:QOSLFM > 2.3.CO;2 
Halbach P, Blum N, Pluger W, van Gerven M, Erzinger J, S. 92 S. S. Party (1995) The Sonne field - first massive sulfides in the Indian Ocean. InterRidge News 12-15

Hellebrand E, Snow JE, Hoppe P, Hofmann AW (2002) Garnet-field melting and late-stage refertilization in "Residual " abyssal peridotites from the Central Indian Ridge. J Petrol 43 (12):2305-2338

Herzig PM, Pluger WL (1988) Exploration for hydrothermal activity near the Rodriguez triple junction, Indian Ocean. Can Mineral 26:721-736

Honsho C, Tamaki K, Fujimoro H (1996) Three-dimensional magnetic and gravity studies of the Rodriguez Triple Junction in the Indian Ocean. J Geophys Res Solid Earth 101(96):837-848

Jean-Baptiste P, Mantisi F, Pauwells H, Grimaud D, Patriat P (1992) Hydrothermal $3 \mathrm{He}$ and manganese plumes at $1939 \mathrm{~S}$ on the Central Indian Ridge. Geophys Res Lett 19(17):1787-1790

Kawagucci S, Okamura K, Kiyota K, Tsunogai U, Sano Y, Tamaki K, Gamo T (2008) Methane, manganese, and helium-3 in newly discovered hydrothermal plumes over the Central Indian Ridge, $18^{\circ}-20^{\circ}$ S. Geochem Geophys Geosyst 9(10):1-14. doi:10.1029/ 2008GC002082

Kumagai $\mathrm{H}$ et al (2008) Geological background of the Kairei and Edmond hydrothermal fields along the Central Indian Ridge: implications of their vent fluids' distinct chemistry. Geofluids 8 (4):239-251. doi:10.1111/j.1468-8123.2008.00223.x

Kuo BY, Forsyth DW (1988) Gravity-anomalies of the ridge-transform system in the South-Atlantic between $31^{\circ} \mathrm{S}$ and $34.5^{\circ} \mathrm{S}-$ upwelling centers and variations in crustal thickness. Mar Geophys Res 10(3-4):205-232

Lin J, Purdy GM, Schouten H, Sempere J-C, Zervas C (1990) Evidence from gravity data for focused magmatic accretion along the Mid-Atlantic Ridge. Nature 344:627-632

Macdonald KC, Miller SP, Huestis SP, Spiess FN (1980) 3-Dimensional modeling of a magnetic reversal boundary from inversion of deeptow measurements. J Geophys Res 85(NB7):3670-3680

Machida S, Orihashi Y, Magnani M, Neo N, Wilson S, Tanimizu M, Yoneda S, Atsushi Y, Tamaki K (in press) Regional mantle heterogeneity regulates melt production along the Reunion hotspotinfluenced Central Indian Ridge. Geochem J

Mahoney JJ, Natland JH, White WM, Poreda R, Bloomer SH, Fisher RL, Bzxter AN (1989), Isotopic and geochemical provinces of the western Indian Ocean Spreading Centers. J Geophys Res Solid Earth 94(88):4033-4052

Mendel V, Sauter D, Patriat P, Munschy M (2000) Evolution of the Central Indian Ridge segmentation with the evolution of the Rodrigues Triple Junction for the past 8 Myr. J Geophys Res 105 (B7):16563-16575

Miranda JM, Silva PF, Lourenço N, Henry B, Costa R, Team S (2003) Study of the Saldanha Massif (MAR, $36^{\circ} 34 \mathrm{~N}$ ): constrains from rock magnetic and geophysical data. Mar Geophys Res 23:299-318

Mitchell NC, Escartín J, Allerton S (1998) Detachment faults at midocean ridges garner interest. EOS Trans AGU 79:127

Morgan WJ (1978) Rodriguez, Darwin, Amsterdam, ..., a second type of hotspot island. J Geophys Res Solid Earth 83(8):5355-5360
Morishita T, Hara K, Nakamura K, Sawaguchi T, Tamura A, Arai S, Okino K, Takai K, Kumagai H (2009) Igneous, alteration and exhumation processes recorded in Abyssal peridotites and related fault rocks from an oceanic core complex along the Central Indian Ridge. J Petrol 50(7):1299-1325. doi:10.1093/petrology/egp025

Munschy M, Schlich R (1988) The Rodriguez Triple Junction (Indian Ocean): structure and evolution for the past one million years. Mar Geophys Res 11:1-14

Murton BJ (2005) Heterogeneity in southern Central Indian Ridge MORB: implications for ridge-hot spot interaction. Geochem Geophys Geosyst 6(3). doi:10.1029/2004GC000798

Nakamura K, Morishita T, Bach W, Klein F, Hara K, Okino K, Takai K, Kumagai H (2009) Serpentinized troctolites exposed near the Kairei Hydrothermal Field, Central Indian Ridge: Insights into the origin of the Kairei hydrothermal fluid supporting a unique microbial ecosystem. Earth Planet Sci Lett 280(1-4):128-136. doi:10.1016/j. epsl.2009.01.024. 21X09000491

Nakamura K et al (2012) Discovery of new hydrothermal activity and chemosynthetic fauna on the central Indian ridge at $18^{\circ}-20^{\circ}$ s. PLoS One 7(3):e32965. doi:10.1371/journal.pone.0032965

Nauret F, Abouchami W, Galer S, Hofmann A, Hemond C, Chauvel C, Dyment J (2006) Correlated trace element-Pb isotope enrichments in Indian MORB along $18-20^{\circ} \mathrm{S}$, Central Indian Ridge. Earth Planet Sci Lett 245(1-2):137-152. doi:10.1016/j.eps1.2006.03.015

Park S-H (2010) Korea national report. InterRidge News 9:34

Parker RL, Huestis SP (1974) Inversion of magnetic-anomalies in presence of topography. J Geophys Res 79(11):1587-1593

Parson LM, Patriat P, Searle RC, Briais AR (1993) Segmentation of the Central Indian Ridge between 12-degrees-12's and the IndianOcean Triple Junction. Mar Geophys Res 15(4):265-282

Sato T, Okino K, Kumagai H (2009) Magnetic structure of an oceanic core complex at the southernmost Central Indian Ridge: analysis of shipboard and deep-sea three-component magnetometer data. Geochem Geophys Geosyst 10(6). doi:10.1029/2008GC002267

Scheirer DS, Macdonald KC (1995) Near-axis seamounts on the flanks of the East Pacific Rise, $8^{\circ} \mathrm{N}$ to $17^{\circ} \mathrm{N}$. J Geophys Res 100 (94):2239-2259

Sempéré JC, Lin J, Brown HS, Schouten H, Purdy GM (1993) Segmentation and morphotectonic variations along a slow- spreading center - the Mid-Atlantic Ridge $\left(24^{\circ} 00^{\prime} \mathrm{N}-30^{\circ} 40^{\prime} \mathrm{N}\right)$. Mar Geophys Res 15(3): 153-200

Takai K, Gamo ÆT, Tsunogai ÆU (2004) Geochemical and microbiological evidence for a hydrogen-based, hyperthermophilic subsurface lithoautotrophic microbial ecosystem (HyperSLiME) beneath an active deep-sea hydrothermal field. Extremophiles 269-282. doi:10.1007/s00792-004-0386-3

Urabe T, Okino K, Sunamura M, Ishibashi J, Takai K, Suzuki K (2009) Trans-crustal advections and in-situ biogeochemical processes of global sub-seafloor aquifer: the Sub-seafloor "TAIGA,". J Geophys Res 118(6): 1027-1036

Van Dover CL et al (2001) Biogeography and ecological setting of Indian Ocean hydrothermal vents. Science 294(5543):818-823. doi:10.1126/science. 1064574 